Warner's letter put an end to the matter, at least temporarily, for penciled at the bottom of the second page of Warner's letter are the initials "WHP" followed by the notation "No answer." The initials are those of Walter Hines Page, an editor in the Houghton Mifflin office doubling as the editor of the Atlantic Monthly.

Brown University

GEORge MONTEIRO

\title{
NOTES
}

1 Bliss Perry, Walt Whitman (Boston and New York: Houghton Mifflin, 1906), p. v.

2 Ms. Houghton Library, Harvard University. Its contents are reproduced here with the permission of the Houghton Mifflin Company and the Library's consent.

3 Probably William Mackintire Salter, the author of "The Great Side of Walt Whitman," Ethical Addresses (September 1899), series 6, no. 7, 121-144; reprinted along with "The Questionable Side of Walt Whitman" as Walt Whitman: Two Addresses (Philadelphia: S. Burns Weston, 1899).

4 Probably Edward Cary, a trustee of the Century Association, New York, and a sometimes member of that club's Committee on Literature.

5 In 1885 Warner had himself contributed to a subscription on Whitman's behalf (Perry, pp. 250-251).

6 Compare Warner's comments on Whitman in 1896: "I wish I could sing the crow! No poet has ever done it, not even Walt Whitman, who might have had a surer hold on immortality by singing the crow than by singing himself" ("Editor's Study," Harper's Magazine [May 1896], 92:961).

\section{“TRANSLATING THE UNTRANSLATABLE": A NOTE ON "THE MYSTIC TRUMPETER"}

"The Mystic Trumpeter," written in 1872 and published in As a Strong Bird on Pinions Free, deserves consideration as a major poem of Whitman's later years. The poem demonstrates the role of the prophetic bard, and the possibility of transcendence from the physical world to a higher reality: it illustrates how music expresses that experience of the higher reality more accurately than does verbal language. Readers of Whitman's poetry are familiar with his conception of the poet as "divine litteratus" who enacts a vision of a New World and as translator of a universal poetry generated before the advent of time. But what in Whitman's early poetry is a quasi-ventriloquist expression of the Self, a belief in the "valvéd voice" of the Soul, is in "The Mystic Trumpeter" something more.

At first glance, the poem is a channel for the poet to transmit a message to his listeners. In Section 1 the poet even states his intention to translate the "capricious tunes" of the "strange musician." To this end he beckons the "wild trumpeter" to come nearer so that his ears alone may "catch thy notes." Despite this resolve to follow the lead of the trumpeter, the poet quickly assumes control over the scenario 
(Section 4). He commands the trumpeter to call up musically, and in sequence, scenes of feudal pageantry, love, war, and human suffering (Sections 4-7). Initially, the poet is immersed in this panorama of sounds, scents and sights, apparently successfully translating them into the poetic line. Dialogue with the trumpeter, however, is transformed into an experience of a higher reality which, paradoxically, is untranslatable.

This new experience, initiated by contact with the mysterious-even mystical-trumpeter, can only be felt, merged with, relaxed into. In Section 3 of the poem, Whitman hints at the possibility of such a transformation. Like Adam walking in the cool evening of Paradise, the poet experiences a "holy calm" and admits to the trumpeter: "Thy song expands my numb'd imbonded spirit - thou freest, launchest me, / Floating and basking upon Heaven's lake." Later he confesses: "Thou melt'st my heart, my brain" (Section 7). But more than heart and brain are melted. By the end of the poem (Section 8) there is no longer any strict correspondence between trumpet tune and message. In effect, language collapses. The poet is bathed in an "ocean fill'd with joy-the atmosphere all joy!" In the midst of this inexpressible experience, the poet exuberantly, yet helplessly, exclaims: "Enough to merely be! enough to breathe!" The significance of this outburst is that more than the poet is affected; indeed, the poem itself is transformed beyond dialogue with the trumpeter into an experience of a transcendent world. This transformation has ramifications for us as audience.

If, as Whitman believed, the poet is enmeshed in the struggle to articulate the inexpressible, the critic who is part of the poet's audience is ensnared in the related dilemma of attempting to explicate that inexpressible moment. Several critics, basing their interpretations on the various contexts of Christian mysticism, Vedantic mysticism, and modern existentialism have proposed solutions to this dilemma in Whitman's poetry. ${ }^{2}$ Although these models of spiritual transformation can be helpful in understanding the resonance of a poem, they fall short of describing what occurs in "The Mystic Trumpeter." Whereas existentialism considers relationship as a series of repeatable actions, "The Mystic Trumpeter" celebrates an achieved state of being; ${ }^{3}$ whereas Christian and Vedantic models of mysticism regard the discovery of the true Self as a passage to a God-centered or a spiritual world that reflects the unity of all being, the poet in "The Mystic Trumpeter" experiences "the rank earth purged-nothing but joy left!" If both poet and critic are to resolve the problem of expressing the inexpressible, some metaphor other than an extrinsic system of thought must be found. I propose the metaphor of music as a solution to this problem.

Whitman's passion for opera and operatic effects is well documented. ${ }^{4}$ In "Proud Music of the Storm," Whitman outlines the power of music to transport him to a transcendent world. All nature's sounds, all songs, dances and instruments are the "clew I sought so long." They are "a new rhythmus fitted for" the soul which enables the poet to fashion "Poems bridging the way from Life to Death," from separateness to the moment of merging into some higher reality. For Whitman, music recollected in tranquility becomes a poem. ${ }^{6}$ To translate the notes of the trumpeter, therefore, is to utter the actual inspiration as well as to convey the inspiring quality of the music. This transforming power of music, described in "Proud Music of the Storm," operates simultaneously on several levels in "The Mystic Trumpeter": music not only transforms the poet's experience and is the bridge to the transcendent world but 
music is the organizing principle of the poem.

Whitman's use of "some strange musician, / Hovering unseen in air" is reminiscent of skylarks and nightingales prominent in Western literature. The unseen bird, noted for making melodies, not only inspires poetic song in others, but also symbolizes the creative process itself. In this poem, the unseen musician is first "in the distance lost," then successively closer until there no longer is any distinction between poet and musician: "methinks I am myself the instrument thou playest" (Section 7). Poet, musician, instrument and melody merge into one transcendent experience.

Moreover, the choice of a trumpet as the musical instrument of the emotional experience is significant. Whitman was keenly aware of the special emotional effect of various musical instruments. The word "trumpet" appears in four poems, "trumpeter" in ten poems, "trumpet-note" and "trumpet-voice" in one poem respectively. ${ }^{7}$ In "The Mystic Trumpeter" the brass instrument deliberately connotes heavenly angels, divine presence, a mystical state, victory in war, victory over self through death or merging, and ritual celebration. The experience of this moment of ecstasy is not the ephemeral pastoral delight associated with a lute or flute, but the triumphant passage to a new and victorious state of being. Use of the trumpet both symbolizes and intensifies that transcendent experience.

The opening stanzas of the poem (Sections 1-3) provide an overture, a stage setting for the musical experience about to be enacted. Each succeeding stanza (4-8) has within it a counterpoint of recitative and aria, brief lines of conversation to advance the narrative balanced by a lyrical and exuberant expansion of the theme. Each stanza (4-8) begins with a command to the unseen musician - for example, "Blow again trumpeter!" - then lapses into a reverie or melodious embellishment of the scene's fascinating sights and sounds. This contrapuntal structure is not a duplication of the rhythmic chanting and unrestrained lyricism which follows a decrescendo to the whispering sea in "Out of the Cradle Endlessly Rocking." The recitative-aria pattern in "The Mystic Trumpeter" illustrates the larger operatic structure of the scena-an emotional climax of a series of recitatives and arias, representing varied moods, that culminates in one "great soul-shaking moment."

Surely such a "great soul-shaking moment" is what the poet experiences at the end of "The Mystic Trumpeter." The poem's progression from simple delight in sensuous detail to blissful happiness of love, to horror and shame at the tableaux of war, and finally to joyous ecstasy of a transcendent vision increases the tempo and complexity of emotional involvement. So intense is the "soul shaking moment" of the climax (Section 8) that the aria possesses a "vigor more than earth's." And so inexpressible is this transcendent experience that the poet cannot explore its meaning through tradition verbal relationships; he can only burst into a "glad, exulting, culminating song." Using "joy" - the last word of the recitative-as a springboard, the poet begins his final aria in a rhapsodic rush of words. With each repetition of "joy"-fourteen in all-the monosyllable loses some of its verbal meaning, gaining at the same time, a musical lyricism beyond language. The effect of this repetition is to break open the poem, to transfigure its shape into a cadenza of wordless vocalizing:

Joy! Joy! in freedom, worship, love! Joy in the ecstasy of life!

Enough to merely be! enough to breathe!

Joy! Joy! all over Joy! 
As the syntactical relationships dissolve, music emerges as the organizing principle of the experience. The emotional climax of the final moments of "The Mystic Trumpeter" is so intense, so inexpressible that the specifics of the experience defy articulation. The poet can only conclude in a delirium of sounds whose musical lyricism must convey the quality of transport. Music is not the background rhythm of this poem but the very shape and language of the experience. What cannot be phrased in words is communicated in the musical form.

Although Whitman indicated in the Preface to As a Strong Bird on Pinions Free E Other Poems (31 May 1872) that all present and future poems are but "surplage forming after 'LEAVES OF GRASS," a study of "The Mystic Trumpeter" calls into question the validity of his disclaimer. ${ }^{9}$ Whitman's self-appointed mission to absorb and express the "colossal drama" of Man makes "The Mystic Trumpeter" more than just a restatement of major themes, a literary biography, or an affirmation of the poet's role as prophetic bard. Rather, this poem extends Whitman's exploration and celebration of the "eternal play" of Man; "The Mystic Trumpeter" is a remarkable achievement of translating the untranslatable.

Nazareth College, Rochester, New York

Monica R. WeIs, SSJ

\section{NOTES}

1 Walt Whitman, "The Mystic Trumpeter," As a Strong Bird on Pinons Free E Other Poems (Washington, D.C., 1872), Barrett Collection, Alderman Library, University of Virginia, Charlottesville, Virginia. All quotations not otherwise identified are from this edition of the poem.

2 Using Evelyn Underhill's model of the progressive stages of mystical union, James E. Miller, Jr. describes the structure and theme of "Song of Myself" as a dramatization of "the emotional states of the mystic as he passes in his experience toward his goal of Union with the Transcendent." "“Song of Myself" as Inverted Mystical Experience," in A Critical Guide to Leaves of Grass [Chicago: University of Chicago Press, 1957], pp. 6-35.) V. K. Chari proposes Vedantic mysticism as a model for interpreting Whitman's poetry; according to Chari's model, Whitman's expansive imagination achieves a kind of cosmic consciousness (Whitman in the Light of Vedantic Mysticism [Lincoln: University of Nebraska Press, 1964]). From yet another viewpoint-the existential philosophy of Martin Buber-Whitman's poetry illustrates the dynamic reciprocity between the self and the world; such interaction provides an integrated, repeatable and transcendent experience of subject-object, I-Thou, the $\mathrm{Me}$ and the Not-Me (see Gay Wilson Allen, $A$ Reader's Guide to Walt Whitman [New York: Farrar, Straus \& Giroux, 1970], pp. 151-152).

3 Allen, Guide, p. 152.

4 See Gay Wilson Allen, The Solitary Singer (New York: New York University Press, 1955), and Robert Faner, Walt Whitman \& Opera (Philadelphia: University of Pennsylvania Press, 1951).

5 Leaves of Grass, Comprehensive Reader's Edition, ed. Harold W. Blodgett and Sculley Bradley (New York: New York University Press, 1965), pp. 403-410.

6 Faner, p. 91. 
7 Faner, p. 125.

8 Faner, p. 117.

9 Whitman, As a Strong Bird, pp. v-vi.

\section{A SOURCE OF WHITMAN'S “THE POETRY OF THE FUTURE”}

In his essay, "The Poetry of the Future," published originally in the North American Review for February 1881 (132: 195-210) and reprinted in Floyd Stovall's edition of Walt Whitman, Prose Works 1892 (New York: New York University Press, 1964), 2:474-490, Whitman quotes at some length from what he describes as "a long and prominent editorial ... on the death of William Cullen Bryant." This editorial, which apparently has not been previously identified, appeared in The Times of London for 14 June 1878. It bore no heading and was indeed inspired by the news of Bryant's death, reported in the issue for 13 June 1878; the main subject was not Bryant, however, but rather the relation between English and American poetry.

It is of some interest to note that, in his essay, Whitman refrained from quoting several passages from this editorial which concerned him personally. The first of these passages Whitman has altered to read: "Unless in a certain very slight contingency, the Times says: 'American verse, from its earliest to its latest stages, seems an exotic. ..."' (Stovall, lines 187-188). The Times editorial actually reads: "Unless Walt Whitman is to be reckoned among the poets, American verse from its earliest to its latest stages seems an exotic. ..."

The second omission is considerably more important. It follows the passage quoted by Whitman (Stovall, lines 201-210) and reads: "Walt Whitman, even without the repulsive eccentricities of his moral tone, must have sunk into obscurity among his countrymen from the want of mannered and borrowed polish which is his special distinction."

It may be that Whitman was a regular reader of The Times and noted the editorial as a matter of course. It seems more likely, however, that someone else came across it and called it to Whitman's attention, because of the references to his work. One might almost suspect that Whitman subscribed to a clipping service, for he was remarkably well-informed concerning even casual criticism of his writings. In any event, The Times editorial in its entirety should be considered an important source of "The Poetry of the Future," and it may even have been the major stimulus to its composition.

Vanderbilt University

W. T. BANDY 